\author{
MARia Śmiechowska, Mariusz JAKubowski, PRZEMYSŁaw DMOWsKi
}

Katedra Towaroznawstwa i Zarzadzania Jakościa

Uniwersytet Morski w Gdyni

Morska 81-87, 81-225 Gdynia

E-mail:m.smiechowska@wpit.am.gdynia.pl marjusz.jakubowski@gmail.com

\title{
NOWE TRENDY NA RYNKU NISKOALKOHOLOWYCH NAPOJÓW FERMENTOWANYCH
}

\section{WSTEP}

Występowanie chorób na tle wadliwego żywienia spowodowało wzrost zainteresowania konsumentów żywnością zawierająca składniki bioaktywne, bezpośrednio lub pośrednio oddziałujące na organizm człowieka (HASLER 1998). Wpływa na to przede wszystkim rozwój dziedzin $z$ zakresu żywności i żywienia. Lepsze zrozumienie powiązań między żywieniem i zdrowiem przyczyniło się do rozwoju żywności funkcjonalnej, co oznacza nowe podejście do produkcji żywności w kontekście poprawy jakości życia i ograniczania ryzyka występowania wielu chorób (SIRO i współaut. 2008).

Żywność funkcjonalna po raz pierwszy pojawiła się na rynku produktów spożywczych w Japonii w 1991 r. W Rozporzadzeniu Ministerstwa Zdrowia i Opieki Społecznej Japonii zdefiniowano ten typ wyrobów spożywczych jako „Żywność o Określonym Zdrowotnym Zastosowaniu" (ang. Foods for Specified Health Use, FOSHU). Żywność FOSHU jest normalna żywnością, $z$ której usunięto szkodliwe składniki (np. alergeny), bądź wzbogacono w substancje aktywne fizjologicznie tak, aby otrzymać produkt posiadający odpowiednia wartość odżywczą, wpływajacy na kondycję człowieka (KOZIOŁKIEWICZ i współaut. 2011). Według FERRARI (2004), zgodnie z definicja Amerykańskiego Stowarzyszenia Dietetycznego, żywnościa funkcjonalną określić można każdy produkt posiadający właściwości pozytywnie oddziałujące na organizm człowieka, poza podstawowymi wartościami odżywczy- mi. Podkreśla się także celowy wpływ spożywania żywności funkcjonalnej, jako źródło dobrostanu fizycznego i psychicznego. Żywność ta przyczynia się do zapobiegania lub zmniejszania ryzyka zachorowań na poszczególne choroby lub poprawia funkcje fizyczne organizmu (OTLES i CAGINDI 2006).

Pośród produktów $z$ grupy żywności funkcjonalnej znaczaca rolę odgrywają napoje. Według FUNCTIONAL DRINKS (2015), światowy rynek napojów funkcjonalnych osiagnał wartość ponad 70 miliardów dolarów w 2014 r., przy skumulowanym rocznym wskaźniku wzrostu (CAGR) wynoszącym 7,8\% w latch 2010-2014. Światowa konsumpcja w tym czasie wzrosła o 7,8\%, osiągając 22 miliony litrów w 2014 r. Zaobserwowano duży wzrost znaczenia rynku napojów funkcjonalnych we wskazanych latach i przewiduje się, że do 2019 r. zjawisko to będzie nadal postępować. Dane te sugeruja, że napoje funkcjonalne stanowią ważna grupe żywności funkcjonalnej. W tym kontekście podkreśla się także znaczenie procesu fermentacji w kształtowaniu napojów o specyficznych cechach organoleptycznych, zmienionym składzie chemicznym, zwiększonej biodostępności składników odżywczych czy zawartości aktywnej mikroflory (TEREFE 2016).

Pochodzenie produktów i napojów fermentowanych jest bardzo różne, wchodzą także w skład wielu diet. W drodze globalizacji i migracji ludności na świecie napoje te wędruja wraz $z$ ludźmi stając się obiektem zainteresowania miejscowej ludności. Z drugiej strony, globalizacja i cie- 
kawość świata spowodowała gwałtowny rozwój turystyki, a turyści na swoich szlakach stykaja się między innymi $z$ nowymi, bliżej sobie nieznanymi produktami żywnościowymi, w tym napojami fermentowanymi. Stad potrzeba, a nawet konieczność przekazywania wiedzy o tych napojach, ich właściwościach i oddziaływaniu na organizm człowieka.

W pracy dokonano charakterystyki procesu fermentacji i wybranych bezalkoholowych funkcjonalnych napojów fermentowanych wytwarzanych metodami domowymi. Opisano takie napoje, jak kombucha, kefir wodny, napoje na bazie serwatki, kwasy chlebowy i buraczany oraz podpiwek. Dodatkowo scharakteryzowano napoje fermentowane pochodzące $z$ różnych rejonów świata.

\section{ZASTOSOWANIE FERMENTACJI W PRODUKCJI ŻYWNOŚCI}

Fermentacja to skomplikowany proces, którego kierunki moga mieć zróżnicowany charakter i konsekwencje. Żywność fermentowana powstaje przede wszystkim w wyni$\mathrm{ku}$ działania mikroorganizmów $\mathrm{w}$ procesie przemian $z$ udziałem enzymów, takich jak amylazy, proteazy, lipazy. Podczas hydrolizy polisacharydów, białek i tłuszczów powstaja produkty nadajace specyficzny smak, aromat i teksturę (STEINKRAUS 1997).

Co istotne, w trakcie fermentacji, powstawanie substancji niebezpiecznych i organizmów patogennych zostaje zahamowane przez metabolity generowane przez bakterie, drożdże i grzyby, które zostały zaszczepione, bądź opanowały środowisko, co dodatkowo wydłuża termin przydatności żywności (TEREFE 2016). Na przykład, $w$ trakcie fermentacji mlekowej, bakterie kwasu mlekowego syntetyzuja takie metabolity jak: kwas mlekowy, kwas octowy, dwutlenek węgla, etanol, nadtlenek wodoru, bakteriocyny czy białka (Di CAGNO i współaut. 2013). Już nasi przodkowie stosowali różnorodne zabiegi $\mathrm{w}$ celu przedłużenia trwałości żywności pochodzenia roślinnego i zwierzęcego, szczególnie produktów o krótkim terminie przydatności i latwo psujących się. Jednym $z$ takich zabiegów była fermentacja. Szacuje się, że żywność fermentowana wywodzi się $z$ Doliny Indusu, a pierwsze ślady stosowania tego procesu pochodza $z$ VII w p.n.e (DANI I MASSON 1992). Przez wieki człowiek rozwijał technologie procesu fermentacji, dzięki czemu nie jest to jedynie zabieg służący zachowaniu właściwości żywności w trakcie długotrwałego przechowywania, ale także nadaniu jej odpowiednich i wyjatkowych cech organoleptycznych oraz zwiększeniu biodostępności składników i wartości odżywczej (TEREFE 2016). Zaobserwować można nawet rozwój biotechnologii w kierunku takiego doboru surowców i mikroorganizmów, aby otrzymać produkt o specyficznych cechach, wymaganych przez konsumenta. Na przykład PEYER i współaut. (2016) omówili dane dotyczace zastosowania wyselekcjonowanych szczepów bakterii kwasu mlekowego (ang. lactic acid bacteria, LAB), w celu otrzymania napojów na bazie surowców zbożowych, charakteryzujących się lepszym smakiem i tekstura. Wskazuje to na szanse zastosowania fermentacji jako naturalnego procesu zapewniajacego unikatowe walory smakowe, niezwykle cenione przez współczesnego konsumenta. Wykorzystanie fermentacji może mieć różny charakter. HugenHOLTZ (2013) zwraca uwage na dwie metody: prosta, tradycyjna, i bardziej złożona, wykorzystywana $\mathrm{w}$ produkcji na skalę przemysłowa. Najprostszym sposobem fermentacji jest przekształcenie produktu tradycyjnego, otrzymywanego w warunkach domowych, w produkt dostępny na szersza skalę. Przykładem może być kefir, tradycyjny napój na bazie mleka, fermentowany przez bakterie kwasu mlekowego i drożdże, o znikomej zawartości alkoholu, spożywany pierwotnie głównie w rejonie kaukaskim i wschodniej Europie (GuZEL-SEYDIM i wspó1aut. 2011). Obecnie kefir produkowany na skale przemysłowa, w wielu krajach jest bardzo popularnym i chętnie spożywanym napojem. Według HugenHOLTZ (2013), innym przykładem popularnego napoju fermentowanego jest kwas chlebowy. Jest to tradycyjny napój na bazie chleba żytniego, $z$ którego przygotowuje się ekstrakt i poddaje się go fermentacji $z$ wykorzystaniem drożdży Saccharomyces cerevisiae. Jak wskazuja dane Rosyjskiego Ministerstwa Edukacji i Nauki (МинистеРство... 2015), duże firmy wykorzystuja dziś ekstrakt kwasu chlebowego, który po rozcieńczeniu woda i ewentualnie poddaniu procesowi fermentacji, rozlewany jest do butelek i sprzedawany pod nazwa "Kwas". Druga metoda produkcji, według HugENHOLTZ (2013) jest próba wykorzystania specyficznych szczepów mikroorganizmów do innego surowca, np. wykorzystanie ziaren kefirowych (syn. grzybki kefirowe, wykorzystywane do otrzymywania fermentowanych napojów mlecznych, tworzone przez bakterie i drożdże) do fermentacji soków owocowo-warzywnych.

Zastosowanie procesu fermentacji w celu kształtowania jakości żywności niesie ze sobą wiele korzyści i wyzwań. Analiza zjawisk zachodzacych $\mathrm{w}$ trakcie tych przemian i umiejętne wykorzystanie zebranej wiedzy może prowadzić do otrzymania nowych napojów funkcjonalnych. 


\section{PRZEGLAD WYBRANYCH NAPOJÓW FERMENTOWANYCH}

$\mathrm{Na}$ ocenę napojów fermentowanych wpływaja dostępne surowce, ich jakość i pochodzenie, zastosowany rodzaj fermentacji, specyficzna mikroflora panujaca w otoczeniu lub zaszczepiona do roztworu, metody produkcji czy warunki środowiskowe (JAKUBOWSKI 2016). Bezalkoholowe napoje fermentowane podzielić można ze względu na kraj lub region pochodzenia, wykorzystany rodzaj surowca, zastosowaną mikroflore, a także skalę produkcji. Jak wspomniano, istnieje duża różnica pomiędzy napojami dostępnymi na rynku i produkowanymi na skalę przemysłowa a napojami wytwarzanymi na potrzeby domowe, przy wykorzystaniu uproszczonych metod produkcji. W ostatnich latach zaobserwowano wzrost zainteresowania produktami i napojami fermentowanymi oraz ich właściwościami, co bez wątpienia przyczynia się do poszerzania działalności wytwórców domowych. Szczególnie silnie to zjawisko występuje obecnie w piwowarstwie domowym, gdzie piwowarzy-amatorzy maja dostęp do szerokiej wiedzy i łatwo dostępnych surowców. Dzięki temu moga wychodzić ze swoimi produktami do większego grona odbiorców, by następnie otwierać niewielkie browary, tzw. rzemieślnicze, lub współpracować z browarami już istniejacymi (MURRAY i O’NEILL 2012).

Jednym $Z$ przykładów napojów fermentowanych, znanych od ponad 2000 lat, jest kombucha. Produkt ten jest głównie spożywany w Azji, Europie Zachodniej i Stanach Zjednoczonych. Przyjmuje się, że nazwa pochodzi od nazwiska koreańskiego lekarza Kombu, który podawał japońskiemu cesarzowi kwaśna herbatę, by wspomóc go w walce $z$ problemami układu trawiennego (TIETZE 1998). Na forach internetowych i w popularnonaukowych publikacjach można spotkać się $z$ wyjaśnieniem nazwy jako składowych słów „Kombu”, które ma oznaczać brazowa alge oraz "Cha”, co oznacza herbatę. Jest to jednak błędna definicja. Napar $z$ brazowych alg, w rozumieniu tej definicji, to napój spożywany w Japonii, którego nie należy mylić $z$ herbata poddana procesowi fermentacji (CRUM i LAGORY 2016). Kombucha powstaje na drodze biochemicznej przemiany sacharozy przez drożdże na cukry proste i niewielkie ilości etanolu, które katalizują reakcję wzrostu bakterii kwasu octowego (JAYABALAN i współaut. 2007). Obecnie obserwuje się znaczacy wzrost sprzedaży tego napoju w Stanach Zjednoczonych, gdzie w 2015 r. szacunkowa wartość tego rynku wynosiła ponad 500 mln dolarów (CRUM i LAGORY 2016).
Z kolei kefir wodny to napój, którego nazwa dotyczy głównego surowca i sposobu fermentacji. Jest to produkt o tyle specyficzny, że do jego otrzymania niezbędny jest około $10 \%$ wodny roztwór sacharozy, w którym zanurza się tzw. ziarna kefirowe, potocznie nazywane „kryształami japońskimi”, "tibicos”, "California bees” czy "Ginger beer plant" (KEBLER 1921) W procesie fermentacji, sacharoza ulega przemianie do kwasu mlekowego, niewielkich ilości kwasu octowego, a także dwutleneku węgla i alkoholu (CORONA i współaut. 2016). Kefir wodny przygotowuje się głównie wykorzystując metody domowe, tym samym skala jego produkcji nie przekracza kilkunastu litrów.

Kolejnymi produktami fermentacji bezalkoholowej, wytwarzanymi na skalę przemysłowa, sa napoje produkowane na bazie serwatki. Badania nad tymi napojami maja na celu wzbogacenie ich witaminami i substancjami poprawiającymi konsystencję oraz dobór odpowiednich dodatków smakowych lub owoców, które poprawią walory funkcjonalne i cechy organoleptyczne (FARAH i współaut. 2016, SOHRABI i współaut. 2016, LIUTKIEVICIUS i współaut. 2016). Zastosowanie tych metod $i$ wdrożenie opracowanych rozwiązań zdaje się być kluczowe, ze względu na specyficzny profil smakowy serwatki, który nie jest akceptowany przez część konsumentów. Dodatkowo, wykorzystanie serwatki do produkcji niskoalkoholowych napojów fermentowanych niesie za soba wiele korzyści, bowiem jest to odpad procesu produkcji sera, który mógłby stać się tanim i wartościowym surowcem.

Kwas buraczany to $z$ kolei tradycyjny napój przygotowywany w Polsce i krajach słowiańskich jako zakwas do produkcji barszczu - tradycyjnej potrawy świątecznej. Napój ten został wpisany na listę produktów tradycyjnych Ministerstwa Rolnictwa i Rozwoju Wsi (www.minrol.gov.pl). Do przygotowanie kwasu buraczanego, podobnie jak innych napojow warzywnych, wykorzystuje się trzy metody prowadzenia fermentacji: spontaniczna, wymuszona przez dodatek kultury starterowej do surowca oraz przez dodatek kultury starterowej do pasteryzowanego soku (ZIELIŃSKA i współaut. 2015). W produkcji domowej $z$ reguły stosuje się metodę spontaniczna, w której bakterie fermentacji mlekowej, pochodzace $z$ powietrza i powierzchni surowca, rozpoczynaja proces fermentacji. Na rynku dostępne sa również napoje na bazie buraka i innych warzyw, które fermentuje się wykorzystując wyselekcjonowane szczepy bakterii, w celu otrzymania specyficznych cech organoleptycznych i probiotycznych. 
Natomiast kwas chlebowy i podpiwek należą do grupy niskoalkoholowych napojów fermentowanych na bazie surowców zbożowych. Kwas chlebowy to tradycyjny napój na bazie chleba żytniego, $z$ którego przygotowuje sie ekstrakt poddawany fermentacji z wykorzystaniem drożdży Saccharomyces cerevisiae. Napój ten również został wpisany na listę produktów tradycyjnych Ministerstwa Rolnictwa i Rozwoju Wsi (www.minrol. gov.pl). Jest to produkt o bogatej i długiej historii, który pierwotnie spożywano na terenach Rosji. Jak wspomniano, produkcja kwasu chlebowego rozwinęła się na szeroka skalę. W Polsce $\mathrm{w}$ latach 60. ubiegłego wieku podejmowane były próby produkcji tego napoju $z$ koncentratów słodowych, m. in. w Łódzkich Zakładach Spożywczych Przemysłu Terenowego (DZIUGan 2008). Podpiwek to tradycyjny polski napój wytwarzany głównie na bazie kawy zbożowej, $z$ dodatkiem chmielu. Chmiel stanowi przyprawę, podobnie jak w produkcji piwa. Na rynku dostępnych jest kilka produktów określonych jako podpiwek. Jednak, podobnie jak w przypadku kwasu chlebowego, raczej należy je zakwalifikować do grupy napojów słodowych lub napojów na bazie surowców zbożowych, ponieważ w wielu przypadkach produkty te nie sa poddane procesowi fermentacji, a ich wytwarzanie opiera się na rozcieńczaniu i nasycaniu dwutlenkiem węgla koncentratów słodowych.

Wśród niskoalkoholowych napojów fermentowanych wymienić można również wiele produktów o charakterze regionalnym lub lokalnym. W Turcji, Bułgarii i krajach bałkańskich bardzo popularne są tradycyjne napoje na bazie surowców zbożowych (boza), rzepy, czarnej marchwi i kaszy bulgur (shalgam), moszczu winogronowego (hardaliye) czy mleka (kefir i ayran) (ALTAY i współaut. 2013). W Afryce natomiast popularne sa odmiany napojów fermentowanych, produkowanych na bazie zbóż i surowców słodowych, takich jak: togwa, mahewu, bushera, koko oraz na bazie mleka: garris, kivuguto, nyarmie, rob czy suusac (MARSH i współaut. 2014).

Shalgam to mętny napój o czerwonej barwie, otrzymywany na drodze fermentacji mlekowej mieszanki rzepy, czarnej marchwi, makki bulgur, soli i wody. Jest produktem często spożywanym w śródziemnomorskim, południowym regionie Turcji, przede wszystkim w okolicach Adany, Hatay i Mersin. Według badań Altay i współaut. (2013), w ostatnich latach shalgam stał się popularny także $\mathrm{w}$ metropoliach takich jak Istambuł, Ankara czy Izmir. Co ciekawe, napój ten dostępny jest również na rynku tureckim w wersji gotowej do spożycia. Uznaje się go za produkt odżywczy ze względu na wysoka za- wartość składników mineralnych, witamin, aminokwasów i polifenoli (ERTEN i współaut. 2008). W napoju shalgam występuja antocyjany pochodzace $z$ soku $z$ czarnej marchwi. W wyniku badań stwierdzono, że zawartość antocyjanów w napojach przygotowanych metodami domowymi jest prawie dwukrotnie większa niż w napojach dostępnych na rynku tureckim (ERCELEBI i OZKANLI 2010).

$Z$ kolei hardaliye to napój również pochodzacy $z$ Turcji, $z$ regionu Marmara. Jest produktem o tyle interesujacym, że do jego otrzymania wykorzystuje się moszcz winogronowy lub sok winogronowy $\mathrm{z}$ dodatkiem ziaren gorczycy i liści wiśni. Proces fermentacji przeprowadza się $\mathrm{w}$ beczkach w temperaturze pokojowej $\mathrm{w}$ czasie 5-10 dni. Napój spożywany jest po filtracji i schłodzeniu (AltaY i współaut. 2013). Produkt ten klasyfikuje sie jako probiotyczny ze względu na obecność bakterii fermentacji mlekowej (PRADO i współaut. 2008). Hardaliye to napój o zasięgu lokalnym. W zwiazku $\mathrm{z}$ tym istnieje potrzeba prowadzenia dalszych badań nad możliwościa wprowadzenia tego produktu na rynek globalny.

\section{SUROWCE I MIKROFLORA NAPOJÓW FERMENTOWANYCH}

Napoje fermentowane są zróżnicowane pod względem wykorzystania surowców i mikroorganizmów. Zrozumienie zależności między surowcami, warunkami środowiskowymi i mikroflora może przyczynić się do sterowania procesem fermentacji i doborem składników w taki sposób, aby powstałe produkty charakteryzowały się wysoka zawartościa składników bioaktywnych i związków łatwo przyswajalnych przez organizm człowieka. Co więcej, zależność między wykorzystanymi surowcami a stosowana mikroflora jest szczególnie znacząca dla cech organoleptycznych produktu, bardzo istotnych dla konsumenta. Surowce i mikroflora omawianych napojów fermentowanych zestawiono w Tabeli 1 .

Wśród mikroflory napojów fermentowanych przeważaja bakterie fermentacji mlekowej, które różnią się głównie szczepami. Co istotne, fermentacji napojów bezalkoholowych na bazie surowców zbożowych towarzyszą drożdże Saccharomyces cerevisiae, których występowania nie stwierdzono w innych tego typu napojach. Drożdże te powoduja hydrolize sacharozy do glukozy i fruktozy $z$ wydzieleniem dwutlenku węgla (BOEKHUT i ROBERT 2006). Charakterystycznym napojem pod względem mikroflory jest kombucha, ponieważ mikroorganizmy zawarte sa nie tylko $\mathrm{w}$ fermentowanym roztworze, ale także $\mathrm{w}$ formie biofilmu, który tworzy się na powierzchni (MALBASA i współaut. 2011, 
Tabela 1. Surowce i mikroflora wybranych niskoalkoholowych napojów fermentowanych. (wg MARSH i współaut. 2014, Altay i współaut. 2013, JAREll i współaut. 2000, DUfresne i FARNwORTH 2000, GUILTZ i współaut. 2011, GUZEL-SEYDIM i współaut. 2011, DluSSKAYA i współaut. 2007).

\begin{tabular}{|c|c|c|}
\hline Napój & Surowce & Mikroflora \\
\hline Kombucha & $\begin{array}{l}\text { Herbata zielona, herbata czarna, od- } \\
\text { pad herbaciany (tea waste); sacharoza }\end{array}$ & $\begin{array}{l}\text { Brettanomyces, Zygosaccharomyces, Saccharo- } \\
\text { myces, Acetobacter xylinum, A. xylinoides, Bac- } \\
\text { terium gluconicum, A. pasteurianus i in. }\end{array}$ \\
\hline Kefir wodny & Woda, sacharoza, owoce & $\begin{array}{l}\text { Lb. casei, Lb. hordei, Lb. nagelii, Lb. hilgardii, } \\
\text { Leuconostoc mesenteroides, Acetobacter faba- } \\
\text { rum, A. orientalis }\end{array}$ \\
\hline Napoje serwatkowe & Serwatka, mleko & $\begin{array}{l}\text { Lb. acidophilus, Lb. casei, Bifidobacterium ani- } \\
\text { malis, Bifidobacterium bifidum }\end{array}$ \\
\hline $\begin{array}{l}\text { Kwas buraczany/ } \\
\text { kwasy warzywne }\end{array}$ & Sok z buraka/soki warzywne & $\begin{array}{l}\text { Lb. plantarum, Lb. mesenteroides, Leuconostoc, } \\
\text { Lactococcus }\end{array}$ \\
\hline $\begin{array}{l}\text { Kwas chlebowy, pod- } \\
\text { piwek }\end{array}$ & $\begin{array}{l}\text { Ekstrakt chleba żytniego, kawa zbożo- } \\
\text { wa, ekstrakty słodowe }\end{array}$ & $\begin{array}{l}\text { Saccharomyces cerevisiae, Lactobacillus casei, } \\
\text { Lactobacillus mesenteroides }\end{array}$ \\
\hline Shalgam & Rzepa, czarna marchew, bulgur & $\begin{array}{l}\text { Lb. plantarum, Lb. brevis, Lb. paracasei, Pedio- } \\
\text { coccus pentosaceus, Lb. buchneri }\end{array}$ \\
\hline Hardaliye & Moszcz winogronowy, ziarna gorczycy & $\begin{array}{l}\text { L. paracasei subsp. paracasei, } \\
\text { L. casei subsp. pseudoplantarum, } \\
\text { L. pontis, L. brevis, L. acetotolerans, L. sanfran- } \\
\text { ciscensis }\end{array}$ \\
\hline Boza & $\begin{array}{l}\text { Proso, kukurydza, pszenica, maka ry- } \\
\text { żowa }\end{array}$ & $\begin{array}{l}\text { Leuconostoc paramesenteroides, } \\
\text { L. sanfrancisco, L. mesenteroides } \\
\text { subsp. mesenteroides, Saccharomyces cerevisiae, } \\
\text { S. uvarum }\end{array}$ \\
\hline Ayran & Mleko & $\begin{array}{l}\text { Streptococcus thermophiles, L. delbrueckii subsp. } \\
\text { bulgaricus }\end{array}$ \\
\hline Togwa & Mąka kukurydziana, słód z proso & $\begin{array}{l}\text { Lactobacillus spp., Saccharomyces cerevisiae, } \\
\text { Candida spp. }\end{array}$ \\
\hline Mahewu & Kukurydza, proso, sorgo & Nieznana. \\
\hline Garris & Mleko wielbłądzie & $\begin{array}{l}\text { Lb. paracasei, Lb. fermentum, Lb. plantarum, } \\
\text { Lactococcus, Enterococcus, Leuconostoc }\end{array}$ \\
\hline
\end{tabular}

MARSH i współaut. 2014). Za powstawanie celulozowej błony na drodze przemiany glukozy w kwas glukonowy odpowiedzialne sa bakterie Acetobacter xylinum (HwANG i współaut. 1999). Celulozowa błona, na której zaobserwować można rozwój mikroorganizmów w trakcie fermentacji, nazywana potocznie „grzybem herbacianym", może być wykorzystywana do otrzymania kolejnych warek napoju (warka - jeden pełny cykl produkcji brzeczki nastawnej).

Mikroflora kefiru wodnego $z$ kolei zawarta jest w formie tzw. „kryształów japońskich", które ze względu na zawartość dekstranu, syntetyzowanego w procesie fermentacji przez bakterie Lactobacillus hilgardii, charakteryzuja się specyficznym kształtem i struktura (GUILTZ i współaut. 2011). Wyko- rzystanie „kryształów japońskich” znajduje również zastosowanie w przypadku fermentowanych soków warzywnych i soków owocowych, co prowadzi do zmiany kwasowości napojów, zawartości składników odżywczych, powstawania alkoholu etylowego i dwutlenku węgla (PEYER i współaut. 2016).

\section{PROCES FERMENTACJI A SKŁADNIKI BIOAKTYWNE I FUNKCJONALNE}

Pochodzenie składników bioaktywnych w niskoalkoholowych napojach alkoholowych wynika ze sposobu wytwarzania i zależy od ich zawartości w surowcach, od rodzaju i właściwości mikroorganizmów, jak np. bakterii fermentacji mlekowej, które moga być dodawane do produktu w celu podwyższe- 
nia jego wartości odżywczych i właściwości funkcjonalnych.

Składniki funkcjonalne pochodzace $z$ surowców znaleźć można przede wszystkim w napojach takich jak: kombucha, napoje serwatkowe czy napoje na bazie soków owocowych i warzywnych oraz napoje na bazie surowców zbożowych, w wyniku obróbki technologicznej (powstawanie związków barwnych w reakcji Maillarda).

Charakter funkcjonalny napoju kombucha może wynikać głównie $z$ wykorzystania naparu herbaty $\mathrm{w}$ procesie fermentacji. Katechiny (epikatechina, gallusan epikatechiny, epigallokatechina, gallusan epigallokatechiny) zawarte $\mathrm{w}$ herbacie maja pozytywny wpływ na organizm, poprzez działalnie przeciwutleniajace polegajace głównie na redukcji wolnych rodników (DUFRESNE i FARNWORTH 2000). Niektóre $z$ efektów wynikających ze spożywania herbaty to: zmniejszone ryzyko chorób serca, zwiększenie odporności, polepszanie stanu kości i zębów czy obniżenie poziomu cholesterolu (DASGUPTA i KLEIN 2014). Udowodniono, że w trakcie procesu fermentacji aktywność antyoksydacyjna i zawartość związków polifenolowych $\mathrm{w}$ napoju kombucha nie ulega istotnym zmianom, przez co właściwości herbaty pozostają również niezmienione (JAYABALAN i współaut. 2007).

Prozdrowotne właściwości omawianych napojów wynikaja również $z$ aktywności mikroorganizmów bioracych udział w procesie fermentacji, głównie bakterii fermentacji mlekowej (Tabela 1), które w odpowiednim stężeniu i środowisku, wprowadzone do organizmu, maja właściwości probiotyczne (MARSH i współaut. 2014). Udowodniono, że istnieje silna zależność między zawartościa i składem aktywnej mikroflory w produkcie a stanem przewodu pokarmowego, co implikuje inne pozytywne efekty w organizmie (MARSH i współaut. 2014).

Składniki zawarte w owocach i warzywach oraz $\mathrm{w}$ produkowanych $\mathrm{z}$ nich sokach, pod wpływem fermentacji staja się bardziej biodostępne, a tym samym lepiej przyswajalne (ZIELIŃsKA i współaut. 2015). Proces fermentacji może również korzystnie wpływać na ilość witamin i kwasów organicznych, niezbędnych dla prawidłowego funkcjonowania organizmu (CORONA i współaut. 2016).

W literaturze można również spotkać wyniki badań dotyczacych poprawy cech organoleptycznych i właściwości zdrowotnych napojow na bazie serwatki. Podejmuje się próby stosowania m.in. inuliny (DRGALIĆ i współaut. 2005), fitosteroli i izoflawonów (SEYHAN i współaut. 2016) czy hydrokoloidów (GALLARDO-ESCAMILLAA i współaut. 2007). Właściwości funkcjonalne serwatki moga również wynikać $z$ jakości samego surowca bogatego w białko.

W grupie niskoalkoholowych napojów fermentowanych na bazie surowców zbożowych najważniejszym produktem na rynku polskim i krajów słowiańskich jest kwas chlebowy. Napój, ten powstający $z$ ekstraktu chleba żytniego lub ewentualnie ekstraktu słodowego, może zawierać błonnik pokarmowy pochodzący $z$ surowca, a także kwas foliowy $\mathrm{i}$ witaminy $z$ grupy $B$, produkowane na skutek działania drożdży (GAMBUŚ i współaut. 2015). W procesie fermentacji w produkcie powstaja kwasy organiczne, a przy niskiej zawartości cukru jest to produkt orzeźwiający i gaszący pragnienie (DZIUGAN 2008).

\section{PODSUMOWANIE}

Zróżnicowanie niskoalkoholowych napojów fermentowanych jest bardzo szerokie, biorąc pod uwagę zarówno ogólny charakter produktów, jak i poszczególne czynniki, takie jak surowce, sposób przygotowania, warunki procesu fermentacji, warunki środowiskowe, wykorzystanie lub obecność specyficznej mikroflory czy długość procesu. Wykazano, że niskoalkoholowe napoje fermentowane charakterystyczne dla danego kraju czy regionu, wytwarzane metodami domowymi stanowia bardzo ważny element kulturowy. Warto zauważyć, że jakość produktu silnie zwiazana jest $Z$ dostępnością surowców w danym regionie, o czym może świadczyć np. wykorzystanie herbaty do produkcji kombuchy, która pochodzi prawdopodobnie $z$ Azji; wykorzystanie buraków do przygotowania kwasu buraczanego, jako surowca o szerokim zastosowaniu w Polsce i krajach słowiańskich czy przetworzenie moszczu winogronowego ze szczepów występujących w Turcji w celu otrzymania napoju hardaliye. W wielu przypadkach obserwuje się wzrost zainteresowania napojami i ich wpływem na zdrowie człowieka, właściwościami i wartościa odżywczą, co często prowadzi do poszerzenia skali produkcji. Na przykład kwas chlebowy, wytwarzany przez wiele wieków w rosyjskich domach, stał się produktem przemysłowym, którego jakość jest regulowana i kontrolowana przez Rosyjskie Ministerstwo Edukacji i Nauki. Innym przykładem może być wymieniona wcześniej Kombucha, której popularność w Stanach Zjednoczonych doprowadziła do powstania nowej gałęzi przemysłu spożywczego. Tureckie napoje shalgam, hardaliye czy boza można spotkać w niektórych sklepach. Produkcja kefiru czy ayranu, mlecznych napojów fermentowanych, doprowadziła do uprzemysłowienia metod produkcji i wkroczenia na rynki europejskie. 
W kilku krajach produkuje się odżywcze napoje na bazie serwatki jako pozostałości po produkcji sera. Przykłady te sugerują możliwości zastosowania procesu fermentacji na szeroka skalę, do otrzymania produktów innowacyjnych, naturalnych, zdrowych i chętnie wybieranych przez konsumentów.

Niskoalkoholowe napoje fermentowane maja wartości zdrowotne i odżywcze. Z licznych badań wynika, że proces fermentacji wpływa na biodostępność składników odżywczych i kształtuje charakter probiotyczny niskoalkoholowych napojów fermentowanych, zwiąany m.in. $z$ obecnościa bakterii fermentacji mlekowej. Wielokierunkowe oddziaływanie na organizm człowieka pozwala na zakwalifikowanie tego typu napojow do segmentu żywności funkcjonalnej, bardzo prężnie rozwijającego się w Europie. Dobór odpowiednich surowców i szczepów mikroorganizmów wraz $z$ metodami produkcji stwarza szanse otrzymywania napojów o powtarzalnej jakości i wysokim bezpieczeństwie, które jednocześnie moga spełniać kilka funkcji i korzystnie oddziaływać na nasze zdrowie.

\section{Streszczenie}

Proces fermentacji od dawna wykorzystywany jest w produkcji żywności. Na początku celem fermentacji było przede wszystkim przedłużenie trwałości produktów. Z czasem zaczęto dostrzegać korzystny wpływ procesu fermentacji na jakość i właściwości żywności. Wśród żywności fermentowanej wyróżnić można napoje niskoalkoholowe, w których znaczaca zawartość składników bioaktywnych i bakterii fermentacji mlekowej pozwala zakwalifikować je do żywności funkcjonalnej. Jest to żywność, z której usunięto szkodliwe składniki (np. alergeny), bądź wzbogacono w substancje aktywne fizjologicznie, tak aby otrzymać produkt posiadający odpowiednia wartość odżywcza, wpływający na kondycję człowieka. W niniejszej pracy scharakteryzowano niskoalkoholowe napoje fermentowane, takie jak kombucha, kefir wodny, kwasy chlebowy i buraczany, napoje na bazie serwatki i podpiwek, a także tradycyjne napoje regionalne, takie jak hardaliye, boza czy shalgam. Przedstawiono pochodzenie napojów, surowce, mikroflorę i występowanie składników bioaktywnych.

\section{LITERATURA}

Altay F., Karbancioglu-Guler F., Daskaya-DiKMEN C., HEPERKAN D., 2013. A review on traditional Turkish fermented non-alcoholic beverages: Microbiota, fermentation process and quality characteristics. Int. J Food Microbiol. 167, 44-56.

BoEkHOUT T., RoBerT V., 2003. Yeasts in food. Woodhead Publishing Limited, Abington Hall, Abington Cambrige CB1 6AH, England.

Corona O., RANDAZzO W., Miceli A., GuARCEllo R., Francesca N., Huseyin E., Moschetti G., SETTANI L., 2016. Characterization of kefir-like beverages produced from vegetable juices. LWT - Food Sci. Tech. 66, 572-581.

CRUM H., Lagory A., 2016. The Big Book of Kombucha. Brewing, Flavoring, and Enjoying the
Health Benefits of Fermented Tea. Storey Publishing LLC, North Adams.

DANI A. H., MAsSon V. M., 1992. History of civilizations of central Asia. Volume I. The dawn of civilization: earliest times to 700BC. UNESCO Publishing, Paris. http//unesdoc.unesco. org/images/0009/000944/094466e.pdf [dostęp: 05.07.2017].

DASGUPTA A., KLEIN K., 2014. Antioxidants in Food, Vitamins and Supplements. Prevention and Treatment of Disease. Elsevier Inc, UK, USA.

Di Cagno R., Coda C., De Angelis M., GobBetti M., 2013. Exploitation of vegetables and fruits through lactic acid fermentation. Food Microbiol. 33, 1-10.

DLuSsKaYA E., JANSCh A., SchwaB C., 2007. Microbial and chemical analysis of a kvass fermentation. Eur. Food Res. Tech. 227, 261266.

Drgalic I., TRATnIK L., BOZANIC R., 2005. Growth and survival of probiotic bacteria in reconstituted whey. Le Lait 85, 171-179.

DUFresne C., FARNWORTH E., 2000. Tea, Kombucha, and health: a review. Food Res. Int. 33, 409-421.

DZIUGAN P.,. 2008. Kwas chlebowy zdrowy $i$ orzeźwiajacy. Przegląd Piekarski i Cukierniczy $6,58-62$.

ERCELEBI E. A., OzKanli O., 2010. A traditional fermented beverage: shalgam juice. The 1 st International Symposium on "Traditional Foods From Adriatic to Caucasus", 15-17 April 2010, Tekirdağ, Turkey, 1019-1020.

ERTEN H., TANGUler H., CANBAS A., 2008. A traditional Turkish lactic acid fermented beverage: shalgam (salgam). Food Rev. Int. 24, 352-359.

FARAH S. J., ARaujo C. B., Melo L., 2016. Analysis of yoghurts', whey-based beverages' and fermented milks' labels and differences on their sensory profiles and acceptance. Int. Dairy J 68, 17-22.

FERRARI C., 2004. Functional foods, herbs and nutraceuticals: towards biochemical mechanisms of healthy aging. Biogeraontology 5, 275-289.

FUNCTIONAL DRINKS, 2015. Global industry guide. http: / / www.yumda.de/marktstudien/1035/ functional-drinks-global-industry-guide.html.

Gallardo-escamillaA F. J., Kelly A. L., DelaHUNTY C. L., 2007. Mouthfeel and flavour of fermented whey with added hydrocolloids. Int. Dairy J. 17, 308-315.

GambuŚ H., Mickowska B., Bartoń H., AuguSTYN G., ZIEĆ G., LITWINEK D., SZARY-SwORST K., BERSKI W., 2015. Health benefits of kvass manufactured from rye wholemeal bread. J. Microbiol. Biotechnol. Food Sci. 4, 34-39.

Guiltz N., Stadie J., Wenning M., Ehrmann M., VoGle R. F., 2011. The microbial diversity of water kefir. Int. J. Food Microbiol. 151, 284288.

GuZEL-SEydiM Z. B., KoK-TAS T., GReEne A. K., SEYDIM A. C., 2011. Review: functional properties of kefir. Crit. Rev. Food Sci. Nutr. 51, 261-268.

HASLER C. M., 1998. Functional foods: their role in disease prevention and health promotion. Food Tech. 52, 57-62.

HugENHOLTZ J., 2013. Traditional biotechnology for new foods and beverages. Curr. Opin. Biotechnol. 24, 155-159.

HWANG. J.W., YANG Y.K., HWANG J.K., 1999. Effects of $\mathrm{pH}$ and Dissolved Oxygen on Cellulose Production by Acetobacter xylinum BRC5 by 
Agitated Culture. J. Biosci. Bioengin. 88,183188.

JakUBOwski M., 2016. Porównanie wybranych fermentowanych napojów bezalkoholowych pod względem wykorzystanych surowców. Badania i Rozwój Młodych Naukowców w Polsce Żywność i żywienie, 71-76.

Jarell J., CAL T., BennetT J. W., 2000. The Kombucha Consortia of yeasts and bacteria. Mycologist 14, 166-170.

JAYABALAN R., MARIMUTHU S., SWAMINATHAN K., 2007. Changes in content of organic acids and tea polyphenols during kombucha tea fermentation. Food Chem. 102, 392-398.

KEBler L. F., 1921. California bees. J Am. Pharm. Assoc. 10, 939-943.

KozIOEKIEWICZ M., NEBESNY E., KRYSIAK W., RoSICKA-KACZMAREK J., BUDRYN G., GAEAZKA-CZARNECKA I., LIBUDZISZ Z., 2011. Żywność i żywienie w XXI wieku. Strategiczny program badawczy. SWSPiZ, Łódź.

LiUTKEVICIUS., SPEICENE V., KAMINSKAS A., JABlONSKene V., Alencikiene G., Miezeliene A., BAGDONAITE L., VITKUS D., GaRMiEnE G., 2016. Development of a functional whey beverage, containing calcium, vitamin $D$, and prebiotic dietary fiber, and its influence on human health. J Food Sci. 14, 309-316.

MALBASA R., LONCAR E., VITAS J. S., CANADOVIĆ-BRUNET J. M., 2011. Influence of starter cultures on the antioxidant activity of kombucha beverage. Food Chem. 127, 17271731.

МИНИСТЕРСТВО ОБРАЗОВАНИЯ И НАУКИ РОССИЙСКОЙ ФЕДЕРАЦИИ, 2015. Technologia produkcji napojów bezalkoholowych i kwasu. Uniwersytet ITMO, Sankt-Petersburg (tłumaczenie własne).

Marsh A., Hill C., Ross R. P., CotTer P. D. 2014. Fermented beverages with health-pro- moting potential: Past and future perspectives. Trends Food Sci. Technol. 38, 113-124.

MurRAY D. W., O'NeILl M. A., 2012. Craft beer: penetrating a niche market. Br. Food J. 114, 899-909.

OTLES S., CAGindi O., 2006. Cereal based functional foods and nutraceuticals. Acta Sci. Pol., Technol. Aliment. 5, 107-112.

PEYER L.C., ZANNINI E., ARENDT., 2016. Lactic acid bacteria as sensory biomodulators for fermented cereal-based beverages. Trends Food Sci. Technol. 54, 17-25.

Prado F. C., Parada J. L., Pandey A., Soccol C. R., 2008. Trends in non-dairy probiotic beverages. Food Res. Int 41, 111-123.

Seyhan E., YAman H., Ozer B., 2016. Production of a whey-based functional beverage supplemented with soy isoflavones and phytosterols. Int. J. Dairy Tech. 69, 114-120.

Siro I., KAPOLNA E., KaPOLNA B., LUGASI B., 2008. Functional food. Product development, marketing and consumer acceptance - A review. Appetite $51,456-467$.

SOHRABI Z., EFTEKHARI M. H., ESKANDARI M. H., REZAEIANZADEH A., SAgheB M. M., 2016. Development and characterization of fermented and unfermented whey beverages fortified with vitamin E. J. Agr. Sci. Tech. 18, 15111521

STEINKRAUS K. H., 1997. Classification of fermented foods: worldwide review of household fermentation techniques. Food Control 8, 311317.

TEREFE N. S., 2016. Food Fermentation. Ref. Module Food Sci. 1, 1-2.

Tietze H. W., 1998. Kombucza - Cudowny grzyb. Podrecznik podstawowy. Poligraf, Wrocław.

ZIELIŃSKA M., HOFFMAN A., WASZKIEWICZ-ROBAK B., 2015. Tradycyjne roślinne napoje fermentowane o działaniu prozdrowotnym. Przemysł Fermentacyjny i Owocowo-Warzywny, 5, 6-9.

Kosmos Vol. 67, 3, 575-582, 2018

Maria Śmiechowska, Mariusz Jakubowski, PrZemystaw DMowski

Department of Commodity Science and Quality Management, Gdynia Maritime University, 81-87 Morska Str., 81-225 Gdynia, E-mail: m.smiechowska@wpit.am.gdynia.pl,marjusz.jakubowski@gmail.com

\section{NEW TRENDS IN FERMENTED LOW-ALKOHOLIC BEVERAGES MARKET}

Summary

Fermentation process has been used in food production since ages. At the beginning, the aim of the process was to extend shelf life of food products. Then people started to see beneficial effects of fermentation process in food quality and properties. Among fermented products, there are several low -alcoholic beverages, which can be described as a functional food, due to their significant content of bioactive compounds and presence of lactic acid bacteria. Functional foods are products of reduced noxious compounds or ones enriched by physiologically active substances, in order to obtain food of a proper nutritional value, improving human constitution. In this paper, low-alcoholic fermented beverages such as kombucha, water kefir, kvass (bread kvass and beet kvass), whey-based beverages, home-brew and traditional, regional drinks such as hardaliye, boza and shalgam were characterized. The origins of the beverages, their substrates, microflora and bioactive compounds are also presented. 